\title{
Fate of the Herbicide Sethoxydim in Sugar Beet
}

\author{
Kanji Ishihara, Hironori Shiotani, Yoshinori Soeda \\ and Shigeo Ono \\ Environmental Toxicology Laboratory, Odawara Research Center, \\ Nippon Soda Co., Ltd., Takada, Odawara 250-02, Japan
}

(Received August 23, 1987)

\begin{abstract}
The behavior of the herbicide sethoxydim, ( \pm )-2-(1-ethoxyiminobutyl)-5-[2-(ethylthio)propyl]-3-hydroxycyclohex-2-enone, in sugar beets (Beta vulgaris) was investigated by leaf treatment of the $\left[{ }^{4-14} \mathrm{C}\right]$-labeled compound. The ${ }^{14} \mathrm{C}$ in treated leaves gradually decreased to $37 \% 7$ days after application. Much of it was translocated to untreated leaves and a little to the root. The amount reached a maximum of $15.9 \%(9.7 \mathrm{ppm}$ as the parent compound) and $4.2 \%(13.4 \mathrm{ppm})$, respectively, on day 3 after treatment, and then decreased to $0.02 \mathrm{ppm}$ or less at the final sampling on day 90 . Sethoxydim was rapidly converted to its sulfoxide and sulfone, and their oxo-tetrahydrobenzoxazole and desethoxyl derivatives, and further to the conjugates of these compounds.
\end{abstract}

\section{INTRODUCTION}

Sethoxydim $\left(\mathrm{Nabu}^{\circledR}\right.$ in Japan or Poast ${ }^{\circledR}$ in the U.S.A.), ( \pm )-2-(1-ethoxyiminobutyl)-5-[2(ethylthio)propyl]-3-hydroxycyclohex-2 -enone, is a post-emergence herbicide which controls gramineous weeds in broadleaf crops such as sugar beet, soybean and cotton. ${ }^{1,2)}$ The herbicide is a new derivative of the grass killer alloxydim-sodium (ADS), sodium salt of 2-(1allyloxyamino)butylidene - 5, 5-dimethyl - 4 methoxycarbonylcyclohexane-1,3-dione, and has been found to have higher herbicidal activity than ADS. ${ }^{3,4)}$ The fate of ADS in sugar beets has been studied in relation to its nonbiological reactions. Studies ADS have shown that is transformed to its desallyloxyl derivative by sunlight and to oxo-tetrahydrobenzoxazole derivatives by heat and in plants. ${ }^{5}$

In the present study, degradation, translocation and metabolism of $\left[4-{ }^{14} \mathrm{C}\right]$ sethoxydim applied on the leaves of sugar beet plants were investigated as one of the studies for safety evaluation.

\section{MATERIALS AND METHODS}

\section{Chemicals}

$\left[4-{ }^{14} \mathrm{C}\right]$ Sethoxydim was synthesized at the Japan Atomic Energy Research Institute and had a specific activity of $10.3 \mathrm{mCi} / \mathrm{mmol}$ and a radiochemical purity of $98 \%$, as checked by two-dimensional thin-layer chromatography using a silica gel plate and solvent systems of $n$-hexane-benzene-acetone $(10: 10: 1)$ and $n$ hexane-acetone $(7: 3)$. Unlabeled sethoxydim and the following authentic compounds were supplied by the Organic Synthesis Laboratory, Nippon Soda Co., Ltd.: Sethoxydim, colorless liquid, bp $>90^{\circ} \mathrm{C} / 4 \times 10^{-5} \mathrm{mmHg}, n_{\mathrm{D}}^{27.5} 1.5229$; 2 - (1 - ethoxyiminobutyl) - 5 - [2 - (ethylsulfinyl) propyl]-3-hydroxycyclohex-2 -enone [designation, M-SO], colorless liquid, $n_{\mathrm{D}}^{24} 1.5256$; $2-(1-$ ethoxyiminobutyl)-5-[2-(ethylsulfonyl)propyl]-

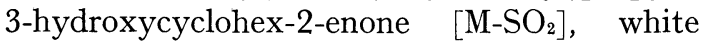
crystals, $\mathrm{mp} 64-66^{\circ} \mathrm{C}$; 2-(1-aminobutylidene)5-[2-(ethylthio) propyl] cyclohexane - 1, 3 - dione [M1-S], white crystals, mp $69.5-70.5^{\circ} \mathrm{C} ; 2-(1-$ aminobutylidene) - 5 - [2 - (ethylsulfinyl)propyl]cyclohexane-1,3-dione [M1-SO], colorless liquid, $n_{\mathrm{D}}^{22} \quad 1.5492$; 2-(1-aminobutylidene)-5-[2-(ethylsulfonyl)propyl]cyclohexane-1, 3-dione [M1- 
$\left.\mathrm{SO}_{2}\right]$, white crystals, $\mathrm{mp} 130-131^{\circ} \mathrm{C}$; 6-[2(ethylthio)propyl]-4-oxo-2-propyl-4,5,6,7-tetrahydrobenzoxazole $[\mathrm{M} 2-\mathrm{S}]$, yellow liquid, $n_{\mathrm{D}}^{22}$ 1.5319; 6-[2-(ethylsulfinyl)propyl]-4-oxo-2-propyl-4, 5, 6, 7-tetrahydrobenzoxazole [M2-SO], colorless liquid, $n_{\mathrm{D}}^{22} 1.5326$; 6 -[2-(ethylsulfonyl)propyl] - 4 - oxo - 2 - propyl-4, 5, 6, 7-tetrahydrobenzoxazole $\left[\mathrm{M} 2-\mathrm{SO}_{2}\right]$, colorless liquid, $n_{\mathrm{D}}^{25.5}$ 1.5309. Their chemical structures were confirmed by $\mathrm{MS},{ }^{1} \mathrm{H}$ - and ${ }^{13} \mathrm{C}-\mathrm{NMR}$ analyses. Pectinase (Aspergillus niger) was purchased from Sigma Chemical Co.

\section{Radioassay and Autoradiography}

Radioactivity was quantified by liquid scintillation counting (LSC; Packard TriCarb ${ }^{\circledR} 3330$ ) with external standardization. Radioactive zones on TLC plates were detected by autoradiography using a medical X-ray film (Fuji Photo Film Co.).

\section{Chromatography}

Thin-layer chromatography (TLC) was performed on 0.2-mm silica gel plates (Merck Art. $5554)$ for metabolite analyses. The solvent systems used and $R f$ values of sethoxydim and its related compounds are listed in Table 1. Authentic compounds were visualized under UV light (254 nm).

A Micropak ${ }^{\circledR}$ SI-10 column (Varian, $2 \mathrm{~mm}$

Table $1 \quad R f$ values of sethoxydim and its related compounds.

\begin{tabular}{lccc}
\hline \multirow{2}{*}{ Compounds $^{\mathrm{a}}$ ) } & \multicolumn{3}{c}{$R f$ values in solvent system $^{\mathrm{b}}$ ) } \\
\cline { 2 - 4 } & $(1)$ & $(2)$ & $(3)$ \\
\hline Sethoxydim & 0.72 & 0.69 & 0.71 \\
M-SO & 0.37 & 0.29 & 0.63 \\
$\mathrm{M}^{-S O}{ }_{2}$ & 0.61 & 0.49 & 0.68 \\
$\mathrm{M} 1-\mathrm{S}$ & 0.64 & 0.54 & 0.70 \\
$\mathrm{M} 1-\mathrm{SO}$ & 0.18 & 0.12 & 0.54 \\
M1-SO & 0.44 & 0.31 & 0.65 \\
M2-S & 0.69 & 0.63 & 0.71 \\
M2-SO & 0.29 & 0.22 & 0.63 \\
M2-SO & 0.52 & 0.40 & 0.68 \\
\hline
\end{tabular}

a) See Fig. 2 for the chemical structures.

b) Composition of TLC solvent systems (v/v, $\%)$ : (1), Dichloromethane-acetone (1: 1); (2), Benzene-chloroform-ethyl acetate-methanol (10:10:10:2); (3), Chloroform-methanol (4: 1). i.d. $\times 50 \mathrm{~cm}$ ) was used for high-performance liquid chromatography (HPLC, Varian 4000 type). Retention times at a flow speed of $0.5 \mathrm{ml} / \mathrm{min}$ and under pressure of $30 \mathrm{~kg} / \mathrm{cm}^{2}$ were $8.1 \mathrm{~min}$ for $\mathrm{M}-\mathrm{SO}$ with $4.5 \%$ methanol in dichloromethane and 11.2 min for $\mathrm{M}_{-} \mathrm{SO}_{2}$ with $0.5 \%$ methanol in dichloromethane.

\section{Plant Treatment}

Two sugar beet plants (Beta vulgaris L., MoNohiLl) were each grown in a Wagner pot $(\phi 16 \mathrm{~cm} \times 18 \mathrm{~cm})$ in a greenhouse. A 1000 ppm aqueous solution of ${ }^{14} \mathrm{C}$-sethoxydim was prepared as follows: ${ }^{14} \mathrm{C}$-sethoxydim (31.8 $\mathrm{mg}$ ) and a surfactant $(11.0 \mathrm{mg})$ were dissolved in xylene $(112.3 \mathrm{mg})$ and then diluted with distilled water $(31.8 \mathrm{ml})$. This solution $(50 \mu \mathrm{l}$, $\left.3.82 \times 10^{6} \mathrm{dpm}\right)$ was dotted with a microsyringe as uniformly as possible on each upper surface $\left(c a .10 \mathrm{~cm}^{2}\right)$ of the first and second true leaves at the third to fourth leaf stage of the plants. The treated plants were cultured outdoors during the day and indoors at night for 8 days ( 4 sunny, 3 cloudy, and 1 rainy), and then outdoors for 82 days (43 sunny, 25 cloudy, and 14 rainy) from June 12 to September 10, 1979. Daily average temperatures measured at $7 \mathrm{am}, 2 \mathrm{pm}$ and $9 \mathrm{pm}$ ranged from 18.1 to $30.1^{\circ} \mathrm{C}$ during the test period. A suitable soil moisture was maintained by supplying water onto the soil surface and an artificial fertilizer was given when necessary. The weight of the root increased from $0.1 \mathrm{~g}$ on day 1 to $12.5 \mathrm{~g}$ on day 90 .

\section{Sampling, Extraction and Analysis of ${ }^{14} \mathrm{C}$ - Compounds}

Two plants were harvested on days $1,3,7$, $15,35,60$ and 90 after the treatment of ${ }^{14} \mathrm{C}$ sethoxydim. The plants were divided into treated and untreated leaves and roots, and then the fresh weights of each part were recorded. The treated leaves obtained on days 1,3 and 7 were separately washed with methanol $(5 \mathrm{ml} \times 3)$, and then were homogenized with $50 \%$ methanol ( $5 \mathrm{ml}$ per gram) using a glass mortar and pestle or a Waring blender. The aqueous methanol extract was separated from the fibrous residue by centrifugation $(3000 \mathrm{rpm}, 5 \mathrm{~min})$. The fibrous residue was re-extracted with $50 \%$ methanol (5 
$\mathrm{ml}$ per gram), and the extract was added to the aqueous methanol extract. The untreated leaves and roots were separately homogenized with $50 \%$ methanol, and extracts were obtained in the same manner. The leaf washing and extracts were radioassayed by LSC. The radioactivity in the fibrous residue was determined after it was converted to ${ }^{14} \mathrm{CO}_{2}$ in a sample oxidizer (Packard Tri-Carb ${ }^{\circledR} 306$ ).

The methanol washing of treated leaves was concentrated at $35^{\circ} \mathrm{C}$ on a rotary vacuum evaporator and the residue was dissolved in dichloromethane and subjected to two-dimensional TLC with solvent system (1) and then with (2) in Table 1. A TLC autoradiogram was prepared (Fig. 1), and the silica gel in the radioactive zones was scraped off to count radioactivity by LSC. ${ }^{14} \mathrm{C}$-Compounds in the methanol washing were also cochromatographed by HPLC with authentic compounds $\mathrm{M}-\mathrm{SO}$ and $\mathrm{M}_{-} \mathrm{SO}_{2}$. The aqueous methanol extract was adjusted to $\mathrm{pH} 3$ and extracted twice with an equal volume of dichloromethane. The dichloromethane extract was concentrated and analyzed to detect metabolites as mentioned above. The aqueous methanol layer was adjusted to $\mathrm{pH} 6$ and concentrated in vacuo at $40^{\circ} \mathrm{C}$ to remove methanol. The aqueous residue was passed through an

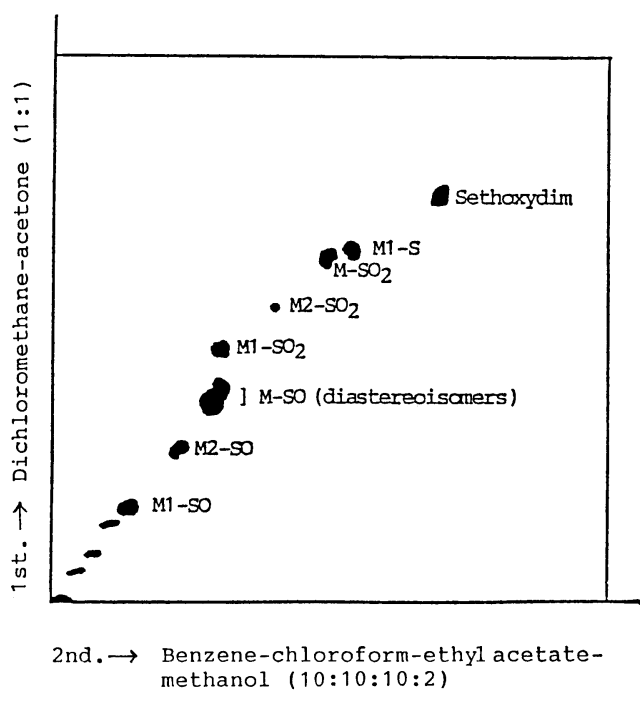

Fig. 1 A typical TLC autoradiogram of ${ }^{14} \mathrm{C}$ compounds in the methanol washing of sugar beet leaves treated with ${ }^{14} \mathrm{C}$-sethoxydim.
Amberlite ${ }^{\circledR}$ XAD-4 column $(\phi 2.2 \times 30 \mathrm{~cm}$ or $\phi 5 \times 30 \mathrm{~cm})$, and the column was washed with distilled water $(0.2-0.5 l)$ and then with methanol $(0.2-1 l)$. The methanol eluate was concentrated in vacuo at $40^{\circ} \mathrm{C}$, and the residue was dissolved in a small amount of ethanol and analyzed by TLC-autoradiography using solvent system (3) in Table 1. Each unknown polar metabolite was extracted with chloroform-methanol $(4: 1)$ from the preparative TLC. A part of the extract, about $2 \times 10^{4}$ $\mathrm{dpm}$, was dried up and dissolved in $10 \mathrm{ml}$ of $0.2 \mathrm{M}$ acetate buffer solution $(\mathrm{pH} 4.0)$ and treated with pectinase $(18 \mathrm{mg}, 20 \mathrm{U})$ at $37^{\circ} \mathrm{C}$ for $4.5 \mathrm{hr}$. The reaction mixture was adjusted to $\mathrm{pH} 2$ and extracted twice with $10 \mathrm{ml}$ of dichloromethane. The extract was radioassayed and subjected to TLC analysis with solvent system (1).

\section{RESULTS AND DISCUSSION}

The behavior of radioactivity derived from ${ }^{14} \mathrm{C}$-sethoxydim applied to the leaf surface of sugar beet plants is shown in Table 2 . The radioactivity gradually decreased with an initial half life of one week. The radioactivity in the methanol washing of treated leaves rapidly decreased to $1 \%$ of the applied radioactivity after 7 days. Large part of it (34\%) in the leaves was found in the aqueous methanol extract. The radioactivity was mainly translocated from treated leaves to untreated leaves and only a small portion to roots. The amount reached a maximum of $15.9 \%$ and $4.2 \%$, respectively, on day 3 and decreased thereafter. The treated leaves fell down naturally before 20 days of cultivation. Sethoxydim-equivalent concentrations based on the fresh weights of untreated leaves and roots decreased to $0.02 \mathrm{ppm}$ or less on day 90 after reaching the maximum of $9.7 \mathrm{ppm}$ on day 3 and 15.4 ppm on day 1 , respectively. In one experiment sethoxydim was rapidly translocated as described above, but it has been reported that ADS does not move so much to untreated leaves, reaching a maximum of $2.1 \%$ on day $10 .^{5)}$ If this difference in translocation is also seen in the case of grasses, it could partly explain that sethoxydim is a more active harbicide than ADS.

The methanol washing and $50 \%$ methanol 
Table 2 Recovery, distribution and concentration of radioactivity in sugar beets after leaf application of ${ }^{14} \mathrm{C}$-sethoxydim.

\begin{tabular}{|c|c|c|c|c|c|c|c|c|}
\hline \multirow{2}{*}{\multicolumn{2}{|c|}{ Plant part \& fractiona ${ }^{a}$}} & \multicolumn{7}{|c|}{ Days after application } \\
\hline & & 1 & 3 & 7 & 15 & 35 & 60 & 90 \\
\hline \multicolumn{9}{|l|}{ A) $\%$ of applied ${ }^{14} \mathrm{C}$} \\
\hline \multirow{4}{*}{ Treated leaves } & Washing & 13.68 & 5.34 & 0.98 & -b) & - & 一 & - \\
\hline & Extract & 58.11 & 43.25 & 34.13 & 18.29 & - & - & - \\
\hline & Residue & 1.82 & 2.37 & 2.04 & 2.38 & - & - & - \\
\hline & Subtotal & 73.61 & 50.96 & 37.15 & 20.67 & - & - & 一 \\
\hline \multirow{3}{*}{ Untreated leaves } & Extract & 4.45 & 13.92 & 10.36 & 9.07 & 9.03 & 4.74 & 0.29 \\
\hline & Residue & 1.09 & 1.96 & 1.47 & 2.47 & 0.71 & 0.21 & 0.05 \\
\hline & Subtotal & 5.54 & 15.88 & 11.83 & 11.54 & 9.74 & 4.95 & 0.34 \\
\hline \multirow{3}{*}{ Roots } & Extract & 2.54 & 3.40 & 0.52 & 0.56 & 0.30 & 0.27 & 0.29 \\
\hline & Residue & 0.26 & 0.78 & 0.17 & 0.22 & 0.16 & 0.21 & 0.17 \\
\hline & Subtotal & 2.80 & 4.18 & 0.69 & 0.78 & 0.46 & 0.48 & 0.46 \\
\hline \multicolumn{2}{|c|}{ Whole plant } & 81.95 & 71.02 & 49.67 & 32.99 & 10.20 & 5.43 & 0.80 \\
\hline \multicolumn{9}{|c|}{ B) ppm as sethoxydim equivalent } \\
\hline \multicolumn{2}{|c|}{ Treated leaves } & 70.3 & 58.7 & 38.2 & 28.2 & - & - & - \\
\hline \multicolumn{2}{|l|}{ Untreated leaves } & 3.4 & 9.7 & 6.6 & 5.4 & 0.70 & 0.14 & 0.01 \\
\hline \multicolumn{2}{|l|}{ Roots } & 15.4 & 13.4 & 3.0 & 1.8 & 0.18 & 0.03 & 0.02 \\
\hline \multicolumn{2}{|c|}{ Whole plant } & 28.4 & 25.0 & 16.5 & 10.0 & 0.62 & 0.10 & 0.01 \\
\hline
\end{tabular}

a) Washing: surface washing, extract: $\mathrm{MeOH}-\mathrm{H}_{2} \mathrm{O}$ extract, residue: fibrous residue.

b) Not obtained.

extracts were analyzed by TLC cochromatography (Fig. 1). M-type compounds have many isomers based on the enol-oxime and keto-enamine tautomerism and on the steric dispositions at the oxime moiety. The ratio of abundance of each isomer varied depending upon a solvent. It was proved that one isomer was predominant in nonpolar solvents. Therefore, dichloromethane was used as the final solvent before TLC analysis in order to unify into one isomer. Furthermore, M-SO showed an apparent twin-spot, indicating the presence of diastereoisomer caused by two asynmetric centers of $-\mathrm{S}(\mathrm{O})-\mathrm{CH}\left(\mathrm{CH}_{3}\right)-$, while twin-spots in M1-SO and M2-SO were unclear because of their low $R f$. Material balances of ${ }^{14} \mathrm{C}$-compounds in the methanol washing and $50 \%$ methanol extract are shown in Tables 3 and 4 . Sethoxydim rapidly degraded in the sugar beet plants. It was found mainly in the washing and very little was found in the extracts from treated leaves and other parts at the early stage of the experiment. Major metabolites were sulfoxide M-SO and sulfone $\mathrm{M}-\mathrm{SO}_{2}$, and minor metabolites, M1-SO, M1-SO $\mathrm{S}_{2}, \mathrm{M} 2-\mathrm{SO}$ and $\mathrm{M} 2-\mathrm{SO}_{2}$ on day 7 after treatment. The level of SO-type metabolites was generally higher than that of $\mathrm{SO}_{2}$ type metabolites at the early stages of the experiment. The situation was opposite on day 60 , however. The finding that the major part of M-SO was found in the extract from treated leaves may indicate that oxidation was partially catalyzed by enzymes in addition to direct oxygenation. Such a reaction is reported in sulfur-containing pesticides such as orbencarb $^{6)}$ and propaphos. ${ }^{7)}$ M1-type (desethoxyl derivatives) and M2-type (oxo-tetrahydrobenzoxazole derivatives) metabolites are thought to be produced by light and heat, respectively, on the analogy of ADS transformation. ${ }^{5}$ The mechanism of oxazole-ring formation is explained by Beckmann rearrangement as is the case of ADS. Compounds found in untreated leaves and roots were also mainly $\mathrm{M}-\mathrm{SO}$ and $\mathrm{M}-\mathrm{SO}_{2}$.

${ }^{14} \mathrm{C}$-Components in the water-soluble fractions remaining after dichloromethane extrac- 
Table 3 Balance of ${ }^{14} \mathrm{C}$-compounds in treated leaves of sugar beets.

\begin{tabular}{|c|c|c|c|c|c|c|c|c|c|c|c|c|}
\hline \multirow{3}{*}{ Compound } & \multicolumn{12}{|c|}{$\%$ of applied ${ }^{14} \mathrm{C}$ at time (days) } \\
\hline & \multicolumn{4}{|c|}{1} & \multicolumn{4}{|c|}{3} & \multicolumn{4}{|c|}{7} \\
\hline & $W^{a)}$ & $E^{b)}$ & $\mathrm{C}^{\mathrm{c})}$ & Total & W & $\mathrm{E}$ & $\mathrm{C}$ & Total & W & $\mathrm{E}$ & $\mathrm{C}$ & Total \\
\hline Sethoxydim & 6.28 & 0.20 & 0.00 & 6.48 & 0.51 & 0.12 & 0.00 & 0.63 & 0.04 & 0.03 & 0.00 & 0.07 \\
\hline M-SO & 5.11 & 34.35 & 1.46 & 40.92 & 1.89 & 18.78 & 1.56 & 22.23 & 0.16 & 4.25 & 3.04 & 7.45 \\
\hline $\mathrm{M}-\mathrm{SO}_{2}$ & 0.19 & 6.43 & 1.37 & 7.99 & 0.30 & 4.60 & 2.05 & 6.95 & 0.16 & 3.32 & 4.05 & 7.53 \\
\hline M1-S & 0.62 & 0.00 & 0.00 & 0.62 & 0.15 & 0.00 & 0.00 & 0.15 & 0.00 & 0.00 & 0.00 & 0.00 \\
\hline M1-SO & 0.44 & 1.43 & 0.00 & 1.87 & 1.02 & 3.55 & 0.00 & 4.57 & 0.12 & 0.61 & 0.00 & 0.73 \\
\hline $\mathrm{M} 1-\mathrm{SO}_{2}$ & 0.18 & 0.31 & 0.29 & 0.78 & 0.20 & 0.58 & 0.29 & 1.07 & 0.08 & 0.31 & 0.71 & 1.10 \\
\hline M2-SO & 0.26 & 1.20 & 0.92 & 2.38 & 0.23 & 0.95 & 0.88 & 2.06 & 0.09 & 0.57 & 1.60 & 2.26 \\
\hline $\mathrm{M} 2-\mathrm{SO}_{2}$ & 0.17 & 0.58 & 1.30 & 2.05 & 0.12 & 0.40 & 1.92 & 2.44 & 0.08 & 0.29 & 4.02 & 4.39 \\
\hline Others & 0.43 & 4.50 & 3.77 & 8.70 & 0.92 & 3.03 & 4.54 & 8.49 & 0.25 & 2.40 & 8.93 & 11.58 \\
\hline Water solubles & - & 9.11 & - & & - & 11.24 & & & - & 22.35 & - & \\
\hline Total & \multicolumn{2}{|c|}{13.6858 .11} & $(9.11)$ & 71.79 & \multicolumn{4}{|c|}{$5.3443 .25(11.24) 48.59$} & \multicolumn{4}{|c|}{$0.9834 .13(22.35) 35.11$} \\
\hline $\begin{array}{l}\text { a) Surface w } \\
\text { b) } \mathrm{MeOH}-\mathrm{H}_{2} \\
\text { c) Organo-so } \\
\text { tract. }\end{array}$ & $\begin{array}{l}\text { h. } \\
\text { extrac } \\
\text { ibles ob }\end{array}$ & $\begin{array}{l}\text { ct. } \\
\text { tained }\end{array}$ & after & he pec & se trea & tmen & of wat & er solub & in the & $\mathrm{MeOH}$ & {$\left[-\mathrm{H}_{2} \mathrm{O}\right.$ e } & ex- \\
\hline
\end{tabular}

Table 4 Balance of ${ }^{14} \mathrm{C}$-compounds in the whole plant of sugar beets.

\begin{tabular}{|c|c|c|c|c|c|c|c|}
\hline \multirow{2}{*}{$\begin{array}{l}\text { Plant } \\
\text { part }\end{array}$} & \multirow{2}{*}{ Compound ${ }^{a}$ ) } & \multicolumn{6}{|c|}{$\%$ of applied ${ }^{14} \mathrm{C}$ (days) } \\
\hline & & 1 & 3 & 7 & 15 & 35 & 60 \\
\hline \multirow{10}{*}{ Top $^{b)}$} & Sethoxydim & 6.67 & 0.66 & 0.08 & 0.06 & 0.00 & 0.00 \\
\hline & $\mathrm{M}-\mathrm{SO}$ & 43.82 & 28.74 & 9.65 & 3.34 & 1.23 & 0.43 \\
\hline & $\mathrm{M}-\mathrm{SO}_{2}$ & 8.69 & 11.77 & 11.77 & 5.22 & 1.76 & 1.12 \\
\hline & M1-S & 0.62 & 0.15 & 0.00 & 0.00 & 0.00 & 0.00 \\
\hline & M1-SO & 1.97 & 4.80 & 0.89 & 0.79 & 0.33 & 0.12 \\
\hline & $\mathrm{M} 1-\mathrm{SO}_{2}$ & 0.82 & 1.26 & 1.41 & 1.18 & 0.33 & 0.29 \\
\hline & M2-SO & 2.48 & 2.44 & 2.71 & 1.16 & 1.07 & 0.21 \\
\hline & $\mathrm{M} 2-\mathrm{SO}_{2}$ & 2.16 & 3.16 & 6.06 & 2.66 & 0.92 & 1.39 \\
\hline & Others $^{c}$ ) & 9.01 & 9.53 & 12.90 & 12.95 & 3.39 & 1.18 \\
\hline & Total & 76.24 & 62.51 & 45.47 & 27.36 & 9.03 & 4.74 \\
\hline \multirow{10}{*}{ Roots } & Sethoxydim & 0.02 & 0.01 & 0.00 & 0.00 & $-^{d)}$ & - \\
\hline & $\mathrm{M}-\mathrm{SO}$ & 1.65 & 1.61 & 0.09 & 0.02 & - & - \\
\hline & $\mathrm{M}-\mathrm{SO}_{2}$ & 0.44 & 1.00 & 0.21 & 0.10 & - & - \\
\hline & M1-S & 0.00 & 0.00 & 0.00 & 0.00 & - & - \\
\hline & M1-SO & 0.03 & 0.07 & 0.01 & 0.00 & - & - \\
\hline & $\mathrm{M} 1-\mathrm{SO}_{2}$ & 0.03 & 0.05 & 0.01 & 0.00 & - & - \\
\hline & M2-SO & 0.07 & 0.15 & 0.04 & 0.00 & - & - \\
\hline & $\mathrm{M} 2-\mathrm{SO}_{2}$ & 0.06 & 0.15 & 0.06 & 0.00 & - & - \\
\hline & Others & 0.24 & 0.36 & 0.10 & 0.44 & - & - \\
\hline & Total & 2.54 & 3.40 & 0.52 & 0.56 & 0.30 & 0.27 \\
\hline
\end{tabular}

a) Non-conjugates + conjugates.

b) Treated leaves + untreated leaves.

c) Found in a washing and extract.

d) Not analyzed. 
tion reached the maximum $23.7 \%$ of the applied radioactivity on day 7 in the treated leaves, $7.4 \%$ on day 35 in the untreated leaves and $0.5 \%$ on day 3 in the root. They were partially purified with an Amberlite ${ }^{\circledR}$ XAD-4 column. The radioactivity applied on the column was quantitatively recovered in the methanol eluate. By TLC cochromatography with authentic compounds, small amounts of non-conjugated M-SO, M-SO ${ }_{2}, \mathrm{M} 1-\mathrm{SO}, \mathrm{M} 2-\mathrm{SO}$ and $\mathrm{M} 2-\mathrm{SO}_{2}$ were detected. They were thought to be remaining portions after dichloromethane extraction or released during the procedures from loosely bound components. Unknown components in the leaves and roots showed similar patterns on the TLC autoradiogram. The components were separated into four major components (UK-2, 3, 4 and 5), one minor (UK-1) and the rest. UK-1 to 5 fractions obtained from the TLC of a 7-day treated-leaf sample were treated with pectinase. The enzyme had liberated larger amounts of aglycons than cellulase or $\beta$-glucosidase in a preliminary experiment. Though hydrolysis in $1 \mathrm{~N}$ hydrochloric acid at room temperature and $37^{\circ} \mathrm{C}$ for $4.5 \mathrm{hr}$ had given similar results to the pectinase treatment, the pectinase hydrolysis was adopted because of its milder conditions. Pectinase effectively converted these unknown components into aglycons extractable with chloroform, and TLC autoradiograms revealed that the unknown components produced known aglycons, i.e. M-SO, $\mathrm{M}-\mathrm{SO}_{2}, \mathrm{M} 1-\mathrm{SO}_{2}, \mathrm{M} 2-\mathrm{SO}$ and $\mathrm{M} 2-\mathrm{SO}_{2}$ (Table 3). The methanol eluates obtained from Amberlite ${ }^{\circledR}$ XAD-4 column treatment of 60-day samples had so many plant materials to separate ${ }^{14} \mathrm{C}$ components through TLC that part of them was directly treated with pectinase without TLC separation. It is uncertain if enzymereleased $\mathrm{M} 2-\mathrm{SO}$ and $\mathrm{M} 2-\mathrm{SO}_{2}$ were present as conjugates or not, considering the chemical structures. The summary of metabolites in total plants is in Table 4 . Non-conjugated

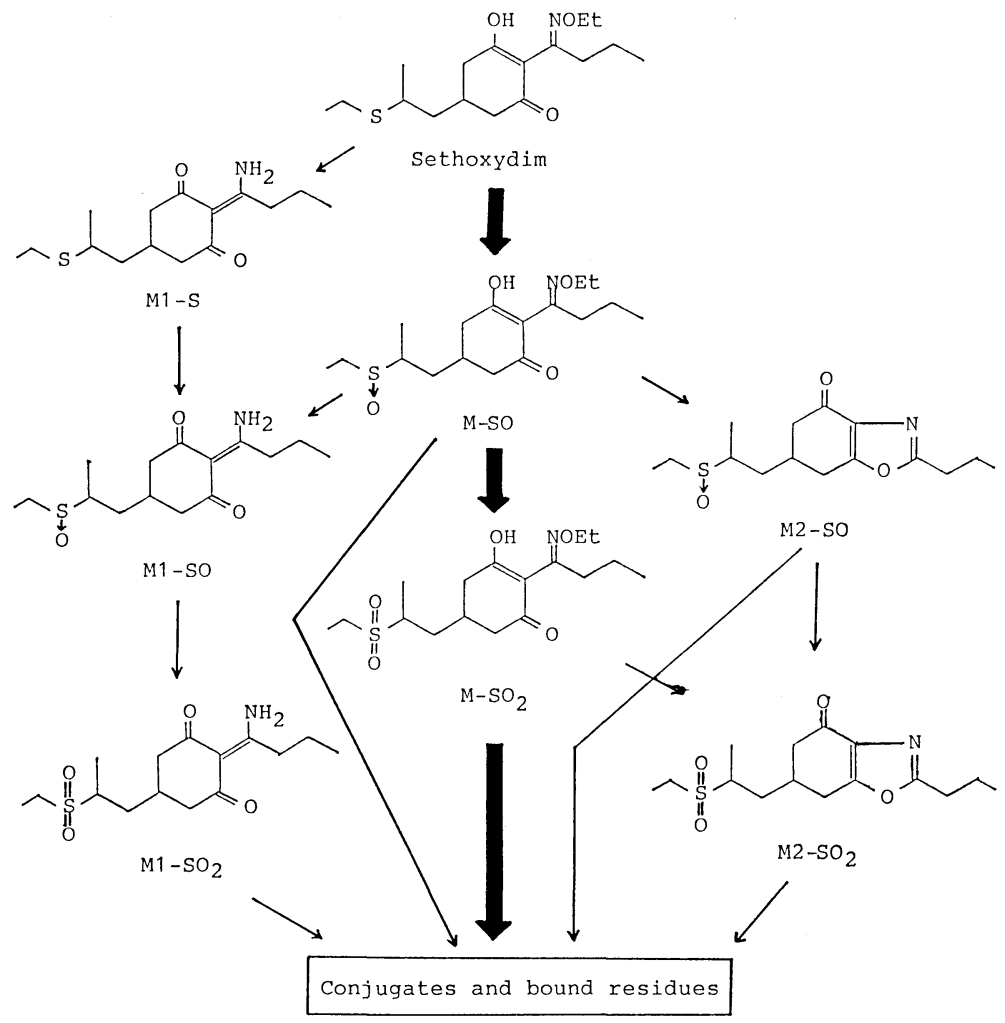

Fig. 2 Proposed metabolic pathways of sethoxydim in sugar beets. 
M-SO was the major metabolite at the early stage, but enzyme-released $\mathrm{M}-\mathrm{SO}_{2}$ and $\mathrm{M} 2-\mathrm{SO}_{2}$ were the major metabolites on day 60 after treatment. The metabolic pathways of sethoxydim in sugar beets are proposed in Fig. 2. All these non-conjugated metabolites should be regarded as target compounds when a crop residue is analyzed, although their toxicity to mammals is low. ${ }^{8)}$

\section{ACKNOWLEDGMENTS}

The authors wish to express their thanks to Prof. Izuru Yamamoto, Tokyo University of Agriculture, for his valuable discussion. The authors also thank the members of Odawara Research Center, Nippon Soda Co., Ltd., for the supply of the chemicals and their technical assistance.

\section{REFERENCES}

1) I. Iwataki, M. Shibuya, H. Ishikawa \& T. Kawana: Jpn. Pat. 144548 (1978)

2) H. Ishikawa, S. Yamada, H. Hosaka, T. Kanawa, S. Okunuki \& I. Iwataki: Abstr. IX Int. Congr. Plant Prot., No. 830, 1979

3) H. Hosaka, H. Inaba, A. Satoh \& H. Ishikawa: Weed Sci. 32, 711 (1984)

4) H. Ishikawa, S. Yamada, H. Hosaka, T. Kawana, S. Okunuki \& K. Kohara: J. Pesticide Sci. 10, 187 (1985)
5) Y. Soeda, K. Ishihara, I. Iwataki \& H. Kamimura: J. Pesticide Sci. 4, 121 (1979)

6) M. Ikeda, T. Unai \& C. Tomizawa: J. Pesticide Sci. 11, 97 (1986)

7) M. Koshioka, J. Kanazawa \& T. Murai: $J$. Pesticide Sci. 11, 557 (1986)

8) O. Saika \& T. Nishibe: unpublished observation (1980)

要 約

\section{除草剤セトキシジムのサトウダイコンにおける 運命}

石原莞爾，塩谷廣範，添田吉則，小野成男 除草剤セトキシジムのサトウダイコンにおける挙動を $\left[4-{ }^{14} \mathrm{C}\right]$ 標識 セトキシジムの葉面処理実験により研究し た. 処理葉中の ${ }^{14} \mathrm{C}$ はしだいに減少し，7日後に処理量 の $37 \%$ となり, 主に非処理葉に移行し, 根には少なか った. 移行した ${ }^{14} \mathrm{C}$ 量は，3 日後に最大となり，それぞ れ，15.9，4.2\% であった. 非処理葉, 根におけるセ卜 キシジム換算濃度は，それぞれ，9.7 ppm(処理後 3 日), $15.4 \mathrm{ppm}$ (同 1 日) の最大值となった後減少し，90日後 には，ともに $0.02 \mathrm{ppm}$ 以下となった. サトウダイコン 中で，セトキシジムは速やかに代謝され，スルホキシ ド，スルホン，それらのオキサゾール体，脱エトキシ体 になり，さらに，抱合体となった。 